\title{
Heterogeneous Effects of Financial Development on Tax Revenues: Accounting for Institutional Quality in Sub-Saharan Africa
}

\author{
Sieni Toussaint. OULAI ${ }^{1}$ \\ ${ }^{1}$ Department of Economics, Peleforo Gon Coulibaly University, Côte d'Ivoire \\ Correspondence: Sieni Toussaint. OULAI, Department of Economics, Peleforo Gon Coulibaly University, Côte \\ d'Ivoire.
}

Received: December 20, 2021

Accepted: January 27, $2022 \quad$ Available online: January 31, 2022

doi:10.11114/aef.v9i1.5468

URL: https://doi.org/10.11114/aef.v9i1.5468

\begin{abstract}
Several studies have shown that financial development improves efforts to increase the tax base and tax revenue through different channels. This paper analyzes the effect of financial development on tax revenue conditional on institutional quality for a panel of developing countries over the period 1990-2019. Using a threshold approach, the results indicate that the influence of financial development on non-cash tax receipts is not monotonic and is sensitive to level of institutions. Financial development improves the tax base and tax revenue when the quality of institutions is better. The results point out as well heterogeneousness across countries and over the years counts. Estimates with financial market index confirm the evidence that countries that benefit most from increased tax revenues are those that improve their institutional quality.
\end{abstract}

Keywords: non-resource tax revenue; financial development, institutional quality, PSTR

JEL classification: F14 ; G20 ; E02 ; C24

\section{Introduction}

One of the fundamental questions about financial development is whether or not it leads to tax revenue mobilization. In spite of recent and increased interest of international institutions and investigation on affinity between financial development and taxation, there is a limited number know of detailed financial development effect on tax income Theoretical and empirical articles do not give a definitive answer on this link. However, existing studies on the issue report that financial system development positively influences tax revenue mobilization (Taha and al, 2013; Ilievski,2015). Others analyze the interaction linking financial sector development and tax revenue raising through its effect on the hidden economy. They conclude that financial development by reducing the underground economy increases the tax base and allows for additional tax revenue mobilization (Ahamed, 2016; Bittencourt and al, 2014). Indeed, as Capasso and Jappelli (2013) point out, financial development reduces the size of the underground economy by facilitating access to credit or reducing the costs of credit to previously excluded agents, which helps improve tax revenue collection.

Quality of institutions is an important element in the establishment of relevant and credible policy, advocate that fiscal development effect on tax income may build upon on it. In fact, as pointed out by Alesina and Perotti, (1996) and Alesina et al (1996) the unpredictability of the expected effects of current and future economic policies is generally due to the instability of governments. When governments do not have a clear vision of how to stay in power, they may reconsider, postpone, or even cancel decisions to implement structural reforms (Carmignani, 2003). Thus, the frequent controversies surrounding their decision-making can lead to public distrust of government commitments to provide adequate services and ensure the evolution of economic activity. Participation in a decrease in tax compliance by economic agents (yohou et al, 2016). Thus, the beneficial effects of government-initiated policies may not be effective. In addition, the inability of the entire administration staff, counting the competent staff in responsible for tax issues, is often associated in developing countries with poor institutional quality.

Although existing studies on the relationship between financial development and tax revenue conclude that financial development improves tax revenue collection, fewer examine the interaction of financial development and governance variables on tax income. Nnyanzi et al (2018) who examined this relationship by considering the interaction between financial development, development policy and corruption show that accounting for the institutional framework in the 
relationship linking financial development and tax revenue could produce improved fiscal outcomes in terms of national tax income. While this analysis allows us to highlight the role of governance in the relationship between financial development and tax revenue, it also allows us to capture the link between financial development and tax revenue, few challenges for econometric specifications and the overall financial development and tax revenue literature remain to be addressed. In addition, the inability of the entire administration, including experienced tax professionals, is often associated in developing countries with poor institutional quality.

Objective of the current work is to examine the heterogeneity in link between financial development and tax revenue as a function of governance quality using a smooth threshold panel estimation (PSTR) implemented by González et al. Method strictly tests for any nonlinearity in order to endogenously determine the cut-off level of governance quality where the impact of financial development and tax receipts changes crucially. Moreover, allows us to have time-varying estimates for each country.

Analysis is based on 29 countries in Sub-Saharan Africa. The link between fiscal development and tax revenue, based on the role of the quality of governance in countries, has received little scrutiny to date; fact remains that countries have a certain amount of commonality in terms of tax revenue mobilization, but differ in their quality of governance. In recent years, several reforms have been undertaken in these countries to combat tax evasion and improve performance in tax revenue mobilization. These reforms have generally been undertaken at the level of tax administration with a view to decentralizing tax administration, creating audit offices and setting up it systems. In this context, tax administration should play a key role as efficient tax mobilization is essential to improve tax revenues. However, domestic revenue mobilization remains low compared to the potential of these countries. Indeed, in 2018, proportion of tax to gross domestic product (GDP) that is not weighted in 30 African countries covered by OECD was 16.5 percent lower than that of the OECD area, which was 34.3 percent. Raising the ratio of taxes to GDP in these nations, the role of the financial sector needs to be re-examined, as it is fair to say that the effective combination of a financial system and fiscal policy is an indispensable tool for stimulating growth.

Paper is organized as such: Section 2 reviews the related economic literature. Section 3 and 4 show the empiric description of the specification and the estimated results, respectively, Section 5 presents a sensitivity assessment, and Section 6 wraps up.

\section{Literature Review}

The link between financial development and other variables has been analyzed in several works, but few studies have focused on the effects of financial development on tax revenues. The literature on this relationship can be divided into two parts, one that studies the direct relationship and one that analyzes the indirect relationship.

Analysis of the direct influence of financial development on tax revenues has been done by some researchers. Using the financial index, which is an aggregate index consisting of the depth (size and activity) of the banking system, access to and efficiency of financial institutions and financial markets, the effect of financial development on tax revenue mobilization is analyzed by Lompo (2021) for a sample of 46 developing countries over the period 1995-2017. Its results indicate that the expansion of the financial sector has a positive and meaningful effect on the government's performance tax revenue mobilization. But, degree of economic development, extent of financial openness, and orientation of tax policies differ from one country to another within developing countries could lead to this positive effect. He also finds that, with the exception of financial market efficiency, other elements of financial development significantly affect tax revenue mobilization at the 5\% threshold. Results further indicate that financial institutions and financial markets influence fiscal revenues of developing countries. Lastly, it shws the recording of non-resource tax revenues is positively affected by financial development. Gnangnon (2019) focusing on the channels of international trade and economic growth for analyse financial development influence on fiscal revenue mobilization effort of 104 developing countries from 1980 to 2014. He concludes that there is a positive relationship between financial development and non-resource tax income mobilization effort. Positive action results in greater trade openness, increased diversification of export products, an increase in manufactured exports in overall export commodities, and a larger economic recovery rate. Nnyanzi et al (2018) analyze financial development impact of a multidimensional view on tax revenues by also considering effects of development policy and corruption over period 1990 to 2014. Their results show that there is a positive and significant relationship between financial development, financial institutions, financial markets and tax revenues. They also show that institutional depth is the most important element in tax revenue mobilization. Indeed, a 1\% change in institutional depth produces a $0.26 \%$ change in fiscal revenue. Level of accessibility, depth, and efficiency of financial markets also has a positive action on taxation mobilization but to a lesser degree than institutional depth. They do not provide meaningful evidences in favor of financial market accessibility and efficiency of the financial institutions, even though the potential for the latter seems indisputable. They also emphasize the enabling character of a healthy institutional and policy climate in the pursuit of a lower tax/GDP ratio through capital development. Bassey (2018) uses financial depth, financial market access, financial market efficiency, financial 
institution stability and financial market development over the period 1993-2017 in his analysis. Overall, his results show that financial sector development in Nigeria improves tax income. Specifically, access and depth of development of financial institutions are the primary determinants of revenue collection in Nigeria, followed by depth and stability of financial market development. paper concludes that for businesses and taxpayers to use financial institutions and financial markets in Nigeria to conduct their transactions, they should be well developed in terms of access, depth and stability.

Akçay and al (2016) on the other hand study the impact of tax revenue on financial development and the effect of complementarity between tax revenue and foreign direct investment (FDI) on financial development in emerging markets. They conclude that the effect of complementarity of tax revenue and FDI on financial development is significant and positive in emerging markets. Ilievski (2012) using a panel dataset of 96 countries over the period 1990-2008, finds that stock markets positively influence the government's ability to raise tax revenue. However, compared to the effect of bank deposits, he finds that the banking sector has greater explanatory power. Taha et al (2013), using month-by-month data for the years 1997-2008, shows that a steady-state link exists in the long run between tax revenues and the financing system. As well, existence of a unidirectional causality from the stock market to direct tax revenues, indicating that an increase in stock market activity is likely to improve direct tax revenue collection. Overall, they show that the impact of the financial system on direct tax revenues is more profound in the short run than in the long run. Petrescu (2013) utilizing group data from 72 nations over a 14-year span studies the link between financial sector quality and selected tax revenues. It constructs a composite indicator of financial development consisting of five financial system indicators. These results assert that a qualitative change in the role of financial intermediation as a percentage of GDP increases total tax revenues and tax revenues, while the third indicator, quality of the financial services sector, has no effect on sales, goods or gift tax revenues. Importance of financial markets in generating tax revenues in Pakistan is analyzed by Akram in 2016 using time series data from 1975 to 2014. In the long term, it finds that the number of bank branches and market capitalization has a positive and significant influence on tax revenues. Credit to the public sector has no effect on tax income, but the connection of private sector credit to tax income is bidirectional. In short term, tax revenues are significantly influenced by the number of bank branches and market capitalization.

As for studies investigating the indirect link, they assert that through factors such as foreign trade, shadow economy, the fight against tax avoidance and bribery, financial development influences tax revenue mobilization. Guo and Hung (2020) show analytically that with a more developed financial sector that has lower agency costs, the government of a small, wealthy, open-economy country will increase its optimal probability of tax auditing, leading to better tax compliance. Their basic model also produces an empirically realistic positive correlation between financial development and the ratio of tax revenue to GDP. In an extended framework that allows for size-dependent probabilities of tax detection, they find that, consistent with empirical evidence, large firms comply with the tax while small firms evade it. Capasso and Jappeli (2013) construct a microeconomic index of the informal economy using Italian microeconomic data. Thus, they show that local financial development is associated with a smaller size of the underground economy, controlling for the potential endogeneity of financial development and other determinants of the underground economy. Dabla and al (2008) study this relationship using firm-level data from transition economies and conclude that higher tax compliance costs reduce firms' reliance on bank credit, while a better legal environment is associated with better access to credit, even for financially opaque informal firms. An interactive term between a national measure of tax compliance costs and the level of informal activity is negative and significant, suggesting that the negative association between informality and bank credit is stronger in countries with weak tax administration. Greenwood et al (2007) show that a well-functioning financial system can facilitate the flow commodities and services (business), thus contributing to determination of firms in the foreign market. As result, will lead to increased exports and imports, and the interested country may can to make higher tax income. Particularly, positive influence of global commercial tax income is communicating by help of revenues generated by fees on foreign trade and domestic tax income.

In addition, financial development can help reduce the rate of tax evasion. So, entry external credit is pricey for firms with higher tax evasion use. Financial expanse cheers greater information disclosure of businesses that are increasingly dependent on outside financing. Therefore, developing nations most pretentious by tax avoidance, with some extent of financial development, can lessen tax revenue losses due to tax avoidance. Financial expansion is also likely to be deterrent to black market expansion.

\section{Methodology and Data}

What follows, we briefly present the model and the advantages of the smooth transition panel regression (PSTR) in terms of accounting for institutional heterogeneity in link uniting financial expansion and taxes that are not related to income in SSA countries. Driving force behind the analysis is the assumption that institutional heterogeneity is associated with institutional quality. This assumption determines the likelihood of needed changes and the quality of 
implementation, which in sense affects fiscal development and non-resource-based tax revenues.

\subsection{Model Specification}

Primary objective of this document is to show that the tax revenue implications of fiscal development evolve progressively from period to case and from country to country depending on the government's ability to implement good policies. The quality of governance to implement good policy must reach a certain level (threshold) for fiscal development to be effective. The model that best describes this dual heterogeneity is the PSTR method, implemented by González et al (2005) and Fok et al (2005). It allows coefficients on the effect of financial development on tax revenues that are a function of the level of governance and vary across countries and over time. It is a changing regime model that permit small number of extreme regimes. It is often seen as an extension of the PTR (Panel Threshold Regression) model stated by Hansen (1999) in which the coefficients of some explanatory variables depend on the value of another variable named transition variable. In the PTR model, the modeled regime change is abrupt, while in the PSTR model, the change is modeled by a smooth transition function. Coefficients from the regression are continuous functions of an observable variable within a bounded function of that variable (González et al., 2005). This model accounts for both heterogeneity and temporal variability by allowing the coefficients to change by country and period. As noted befor, institutional quality is our bridging variable. It positively correlated with tax revenue (Aizenman et al., 2019) through its ability to affect the efficiency of tax mobilization and discourage tax evasion, which will result in higher government revenue mobilization (Tanzi and Davoodi, 1997; Ghura, 1998; Torgler, 2003a, b; Torgler et al., 2008; Bird et al., 2008 and 2014; Yohou and al., 2016, Aizenman and al., 2019). Higher government revenues will, in turn, lead to less debt in financing needed infrastructure or better financing conditions for the economy as a whole. We therefore expect a negative correlation of the interaction between institutional quality and our indicator of financial development and financial markets on non-resource tax revenues, but positive effect between financial development and financial markets on non-resource tax revenues. Variable "tax" refers to the proportion of total tax revenue that is not a function of the country's resources as percentage of gross domestic product. It reflects the difference between total taxation revenues without subsidies and payroll taxes (as percentage of GDP) and resource taxation revenues (as percentage of GDP), latest being the tax revenues raised on natural resources. Choice of using non-resource tax revenues as a percentage of GDP as dependent variable rather than the ratio of total tax revenues to GDP is explained by the following factors following Brun and al (2015) and Gnangnon and Brun (2017, 2018) which have pointed out that government financial resources are vastly outside scope of economic policy. Moreover, the use of tax revenues that are not linked to revenue variable allows for increasing consistency across the nations in the set with respect to total fiscal revenues or government revenues. (i.e., including mixed tax and other revenue). The quality of institutions is captured by a composite index using a principal component analysis on global governance indicators (WGI; Kaufmann and al, 2009) 6 indices and the full WGI database including all the surveyed countries to allow international comparison.

The key variable of interest is the overall financial development index which is further formalized by Svirydzenka (2016) on behalf of the International Monetary Fund. The index is indeed a combination of 20 indicators, including financial institutions (banking and non-banking sector) as well as financial market (the stock market) indicators. Thus, financial institutions and markets are two sub-indices of the overall financial development index. Each of the sub-indices is further subdivided into depth, access, and efficiency sub-indicators. As a result, it can be clearly understood that this index better represents the financial system of an economy. A few researchers (Khan and al (2019) and Islam and al (2018)) have recently recommended this index for empirical studies. We also use the financial market index to verify the robustness of our results. The modeling of tax revenue function as part of a panel smooth threshold effect is defined by the following equation:

$$
\text { tax }_{i t}=\mu_{i}+\beta_{c} c_{i t}+\beta_{0} F D_{i t}+\beta_{1} F D_{i t} g \times\left(\text { insti_quality }_{i t}, \gamma, \text { insti_quality }\right)+\beta_{2} X_{i t}+\varepsilon_{i t}
$$

With $i=1, \ldots, n$ being countries and $t=1, \ldots, T$ time periods. Tax variable is tax revenue to GDP proportion, vector, vector variables of control $X_{i t}$ reflects GDP per capita growth annual, agriculture value, manufacturing value, inflation, openness and population. $\beta_{j, c, . .2}$ are the vectors to be evaluated. $\mu_{i}$ and $\varepsilon_{i t}$ are the single fixed effects and the failures, respectively. The failures are considered to be i.i.d. As above said, insti_quality $y_{i t}$ is institutional quality in nation $i$ and period $t$. The bridging function $g \times$ (insti_quality $\left.y_{i t}, \gamma, i n s t i \_q u a l i t y\right)$ is progressive function of the

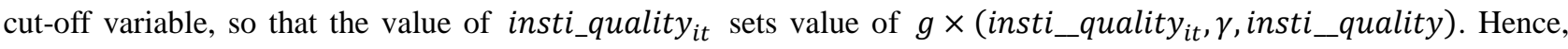
the effect of tax income for nation $i$ at period is as set out below :

$$
\frac{\partial \operatorname{tax}_{i t}}{\partial F D_{i t}}=\beta_{0}+\beta_{1} g \times\left(\text { insti_quality }{ }_{i t}, \gamma, \text { insti_quality }\right)
$$

The value of the transition function ranges from 0 to 1 and defines two peak and trough regimes. If it equal 0 , effect of 
financial development index equals $\beta_{0}$, and if it equals 1 , the financial development index equals $\beta_{0}+\beta_{1}$. Following Granger and Teräsvirta (1993) and González et al. (2005), $g$ takes the next logistic function:

$$
g\left(\text { insti_quality }_{i t}, \gamma, \text { insti_quality }\right)=\left[1+\exp \left(-\gamma \prod_{j=1}^{m}\left(\text { insti_quality }_{i t}-\text { instiquality }_{j}\right)\right)\right]^{-1}
$$

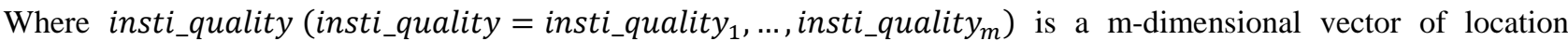
parameters and the estimated term $\gamma$ is the slope of the transition function. A key advantage of the PSTR consists of allowing coefficients of financial development index to vary between countries and over period. It gives a parametric path to model cross-country variability and temporal instability in the coefficients of the financial development index, as these factors vary according to the threshold variable, institutional quality. As a consequence, we are able to estimate many values of the financial development index effect coefficients, lying between $\beta_{0}$ and $\beta_{0}+\beta_{1}$, as country-period observations. However, this results in the difficult task of trying to give sound interpretation to the size of the financial development index estimates in equations (1). Thereupon, the signs of $\beta_{0}$ and $\beta_{0}$ are the only elements that should be interpreted rather than their values. Concerning the slope parameters $\gamma$, establishes form of change function. When it is equal to 0 , the transition function is a fixed value and the pattern corresponds to the normal linear model with the individual impact, i.e. the coefficients are constant and uniform. By contrast, when it tends toward infinity, the transition function becomes an indicator function, the PSTR model translates into the two-regime Panel Threshold Model of Hansen (1999) if $m=1$ for example. If $m>1$ and $\gamma$ goes to infinite, the amount of regimes stays 2 while the function toggles through 0 and 1 (Colletaz and Hurlin., 2006).

Positive relationship should exist through tax revenues and real GDP per capita, based on the assumption that economic expansion increases the need for both government services and the size of fiscal pool. Openness exchange is calculated as combined exports and imports as share of GDP.

Economic structure is measured by agricultural and industrial surplus value as a proportion of GDP. Agriculture ocapital importance in total production and job, which is mostly a sessional activity, limits opportunity of taxation in a system of modern taxation involving personal income tax and taxes on added value (Tanzi and Zee, 2000). Informal sector can also be tied to agriculture (Mahdavi, 2008) is bureaucratically difficult to charge (Fox and Gurley, 2005). Also, since this sector is labor intensive, it sometimes resorts to employing children at the cost of schooling. It has very little use of government services and activities (Tanzi, 1992) and is linked to extremely low fiscal rates. Comparison, industrial segment is more responsive to fiscal opportunities (Clist and Morrissey, 2011).

Inflation, defined as percentage variation in the consumer price index, is thought to be harmful to tax revenues by adversely affecting own real value according to so- called Oliveira-Tanzi phenomenon.

Business taxes are most likely to be easy to collect. Trade openness because of the considerable risks involved should receive special attention from the government in terms of social insurance as Rodrik (1998) and Gupta (2007) point out. But the various commercial liberalization reforms that are being implemented in the region, as in all developing countries, do not seem to be having the desired effect (Agbeyegbe and al., 2006; Benedek and al., 2012).

Population growth captures the role of changes in demographics. of land area. A negative sign is expected.

\subsection{Estimations and Tests of the Specification}

Following Gonzales et al. (2005) and Colletaz and Hurlin (2006), estimation technique involves elimination of individual effects $\mu_{i}$ by dropping the individual-specific average values and running the non-linear least squares on the converted model. González et al (2005) suggest a 3-step test method as shown below: (i) test linearity with respect to the PSTR model, and (ii) identify the set, $r$, of transition functions, i.e., number of extreme schemes that is equal to $r+1$. Linearity check in the PSTR model may be done by testing: $H_{0}: \gamma=0$ or $H_{0}: \beta_{0}=\beta_{1}$. Nevertheless, the tests are non-standardized under the null hypothesis because the PSTR model contains unidentified nuisance parameters. This

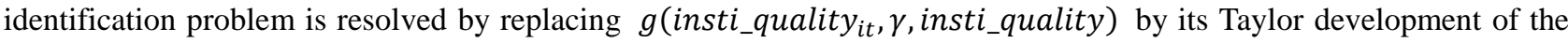
first order around $\gamma=0$ and testing with an equal assumption according to the subsidiary regressions :

$$
\operatorname{tax}_{i t}=\mu_{i}+\beta_{0} * X_{i t}+\beta_{1} * X_{i t} \text { insti }_{\text {quality }}+\cdots+\beta_{m} * X_{i t} \text { insti }_{\text {quality }}^{m}+\varepsilon_{i t}^{m}
$$

The test of linearity of financial development index - tax revenue versus PSTR is then the same as to test $H_{0}: \beta_{1}=$ $\cdots=\beta_{m}^{*}=0$ in equation (4). If we consider $S S R_{0}$ sum of the quadratic residuals of the panel under $H_{0}$, and $S S R_{1}$ sum of panel quadratic residuals with the plans, the corresponding F-statistic is then given by :

$$
L M F=\frac{\left(S S R_{0}-S S R_{1}\right) / m k}{S S R_{0} /(T N-N-m k)} \sim F(m k, T N-N-m(k+1))
$$


Where $k, T$ and $N$ are the number of explicit variables, periods, and countries, respectively. Test of linearity/homogeneity helps to identify in order of sequence amount of changes in model. Considering PSTR model, null assumption that model is straight line is tested at a predetermined level of significance $\alpha$. If discarded, two-regime PSTR model is approximated and tested. If two-speed model is in this case refused, a three-speed model is considered. Operation proceeds up to the point where the first assumption, i.e. the null condition of no residual heterogeneity, is satisfied. At each stage of operation, significance level must be decreased by a constant factor $0<r<1$ to avoid excessively large models (Fouquau and al, 2008).

A potential indigeneity bias issue could arise as countries with limited tax revenue would be keen to improve their financial development index. Nevertheless, considerable theoretical and empirical proof exists that the value and effect of the threshold in models using the Hansen (1999) PTR and PSTRs do not need to be inventoried to be able to identify them (Yu, 2013; Yu and Philipps, 2018), otherwise they could provide inconsistent estimates. Fouquau and al (2008), Béreau and al. (2012) and Jude and Levieuge (2013) In particular, they show that PSTR reduces endogeneity issue since it supplies a specific value of the metric for each cutoff level. variable ${ }^{1}$.

\subsection{Data}

The analysis is based on an unrounded panel from 1990 to 2019 of 29 Sub-Saharan African countries. Data are three-year averaged to achieve an acceptable critical level of observations and to smooth business cycles. Sub-periods are: $\quad 1990-1992=1 ; \quad 1993-1995=2 ; \quad 1996-1998=3 ; 1999-2001=4 ; \quad 2002-2003=5 ; \quad 2004-2006=6 ; \quad 2007-2009=7$; $2010-2012=8 ; 2013-2015=9 ; 2016-2009=10$. The choice of the period and number of countries covered is driven by data availability. Tax revenues is from Public Revenue dataset of the International Center for Taxation and Development (Prichard, 2014; McNabb, 2017). Overall financial literacy index used as a yardstick for financial literacy comes from International Monetary Fund's Financial Development Index database. Institutional quality is taken from the global governance indicators (WGI) database. WGI measures are most often utilized empirical research to judge the political risk and the institutional capacity. Unlike studies that focus on a specific variable, though, build institutional quality hint, which is aggregate of the 6 core constituents in class starting from -2.5 to 2.5 score. List includes: control of corruption, government effectiveness, political stability and absence of violence/terrorism, regulatory quality, rule of law and voice and accountability. Higher the value of component, the lower the associated risk perceived. Annual growth per capita, agriculture value, manufacture value, population growth and openness were obtained from the World Development Indicators (WDI) of the World Bank. Inflation data are taken from the International Monetary Fund's World Economic Outlook (WEO) database.

\section{Results}

As a first step in our regressions, we run simple panel regressions including an interactive term between institutional quality and non-resource tax revenues as is the case in the traditional econometric conditional effect analysis. Next, we will present the results of the smooth threshold panel estimation.

\subsection{Simple Panel Regressions}

For the dependent variable, we consider two models to check the robustness of the results and the sensitivity of our variables of interest (institutional quality, financial development, financial markets and their interaction) including the control variables. The first regression focuses on the first variable of interest which is financial development and the second on the second variable of interest which is financial markets.

The results of the simple panel estimates are summarized in Table 1. First and foremost, we should keep in mind that efficiency of non-resource tax income mobilization is represented by a positive sign in link between the financial measure and tax revenues, which are not a function of resources, while a negative sign implies a reduction in non-resource tax revenue. Thus, in the model with financial development as the dependent variable, the results show that financial development has a positive but insignificant effect on non-resource tax revenue. Financial development-institutional quality conditional variable, on the another, has detrimental affected fiscal revenues that do not have their own financial means and is also not significant. The interactive term between financial development and institutional quality has a negative but insignificant effect on non-resource tax revenues. For the estimation with financial market parameter. We observe that the stock market has a positive and significant effect on non-resource tax revenues. This means that a deepening of the financial market leads to an increase in non-income fiscal revenues. Institutional quality has a positive but insignificant effect on non-resource tax revenues. The interaction between the financial market and institutional quality has a negative and significant effect on non-resource tax revenues.

\footnotetext{
1 Nonetheless, we run additional instrumental regressions for robustness purposes using a S-GMM. We will not be presenting the corresponding results here to save space and focus on the essential as they do not change the key conclusion of the current paper. Results are available upon request.
} 
With respect to the control variables, the results are with a few exceptions consistent with what we expect. In both our estimates, the growth rate of GDP per capita has a positive but insignificant influence on non-resource tax revenues. Share of agriculture in GDP has negative and significant effect in both models. This reflects fact that an increase in the share of agriculture leads to a loss of non-resource tax revenues. The share of the manufacturing sector in GDP also has a significant negative effect on non-resource tax revenues, so an increase in the manufacturing sector cause decrease in non-income fiscal revenues. This is contrary to our expectations. Inflation measured by the consumer price index has a negative effect on tax revenues in both estimates, but this effect is not significant. The relationship between trade openness and non-resource tax revenues is positive and significant. Thus, openness to trade improves tax revenue mobilization capacity. Population growth has a negative and insignificant effect on tax revenues in the model with financial development. On the other hand, its effect is positive in the model with the financial market but this impact is not meaningful.

In end, the estimates of panel interactive linear models do not allow us to draw a definitive conclusion on the effect of our variables of interest, in particular the conditional variables financial development and financial markets as a function of institutional quality, on non-resource tax revenues. This should not be surprising since these regressions consider the effect of the different interest and control variables non-income fiscal revenues mobilization to be homogeneous across nation and over time. In order to relax this strong assumption of intertemporal and individual heterogeneity, we use the PSTR model.

Table 1. Interaction institutional quality/financial development, financial markets and tax revenue

\begin{tabular}{|c|c|c|c|c|}
\hline \multirow[t]{3}{*}{ Dependent variable } & \multicolumn{4}{|c|}{ Non-resource tax revenues } \\
\hline & \multicolumn{2}{|c|}{ Financial development } & \multicolumn{2}{|c|}{ Financial Market } \\
\hline & Coef & T-Student & Coef & T-Student \\
\hline Financial development & 7.714 & $(1.18)$ & & \\
\hline Financial Market & & & $18.116 * * *$ & $(2.75)$ \\
\hline Institutional quality & -0.454 & $(-0.91)$ & 0.156 & $(0.25)$ \\
\hline Financial develop*Institutional quality & -1.717 & $(-0.51)$ & & \\
\hline Financial Market*Institutional quality & & & $-6.600 * *$ & $(-1.95)$ \\
\hline Control variable & & & & \\
\hline GDP per capita growth & 0.072 & $(0.93)$ & 0.094 & $(1.25)$ \\
\hline Agriculture share in GDP & $-0.172 * * *$ & $(-3.91)$ & $-0.134 * * *$ & $(-3.08)$ \\
\hline Manufacturing share in GDP & $-0.183 * * *$ & $(-2.62)$ & $-0.156 * * *$ & $(-2.30)$ \\
\hline Inflation & -0.005 & $(-0.85)$ & -0.003 & $(-0.53)$ \\
\hline Trade Openness & $0.096 * * *$ & $(6.30)$ & $0.100 * * *$ & $(6.74)$ \\
\hline Population growth & -0.038 & $(-0.09)$ & 0.094 & $(0.22)$ \\
\hline constant & $12.833 * * *$ & $(5.13)$ & $8.782 * * *$ & $(3.19)$ \\
\hline Observations & 228 & & 228 & \\
\hline Prob $>F$ & 0.000 & & 228 & \\
\hline R-squared & 0.270 & & 0.322 & \\
\hline Number of id & 29 & & 29 & \\
\hline
\end{tabular}

Source: Authors' estimates. Sample deviations in brackets. *** $\mathrm{p}<0.01, * * \mathrm{p}<0.05, * \mathrm{p}<0.1$.

\subsection{Panel Smooth Threshold Regressions Results}

As we show in the previous section, PSTR requires to first test the hypothesis of linearity. For the regressions, we adopt the same approach as in the simple panel regressions allowing the linearity tests to discriminate about the suitable specifications. Table 2 reports the linearity tests of the final specifications only; this done in order to save space. The results show that for all specifications, the null assumption of linearity is defeated. But no-remaining non-linearity tests fails to reject the null hypothesis of one regime against the alternative of at least two extreme regimes, suggesting one transition process between two extreme regimes.

Tableau 2. Linearity tests

\begin{tabular}{lcccc}
\hline \multicolumn{1}{l}{ Dependent variable } & \multicolumn{2}{c}{ Non-resource tax revenues } \\
\cline { 2 - 5 } & \multicolumn{2}{c}{$\begin{array}{c}\text { Financial } \\
\text { Development }\end{array}$} & \multicolumn{2}{c}{$\begin{array}{c}\text { Financial } \\
\text { Market Dev }\end{array}$} \\
\cline { 2 - 5 } Tests & Linearity & r=1 VS r=2 & Linearity & r=1 VS r=2 \\
\cline { 2 - 5 } Wald Tests (LM) & 24.671 & 0.564 & 8.892 & 6.401 \\
p-value & 0.001 & 0.999 & 0.002 & 0.494 \\
Fisher Tests (LMF) & 3.328 & 0.063 & 1.113 & 0.734 \\
p-value & 0.002 & 1.000 & 0.003 & 0.643 \\
LRT Tests (LRT) & 26.110 & 0.565 & 9.070 & 6.492 \\
p-value & 0.000 & 0.999 & 0.002 & 0.484 \\
\hline
\end{tabular}

Source: authors estimations 
Table 3 reports the different estimated parameters. Slope parameter is higher in the model with financial development than in the model with the financial market. In the regression with the financial development on tax revenues that are not based on income, the estimated threshold is 0.0525 versus 0.1574 in the model with the financial market - three times higher than in the financial development specification. These results suggest that institutional quality is essential to improving non-resource tax revenues if a country wishes to increase its non-resource tax revenues.

Figure 1 plots the elasticities of the financial development and financial market variables conditional on the institutional quality index for every regression. They provide evidence that an increase in our threshold variable, institutional quality, is linked to the negative correlation between financial development and tax revenue, which is not a function of income in the superior regime. Financial market models, lower level of institutional quality is associated again with negative link between financial markets and revenue mobilization in higher regime. However, slope parameters of the two models are 351.6828 and 60.4224 , respectively, which would seem to imply that the shape of the transition is abrupt for both models. Moreover, the two model exhibits the highest RSS which indicates that it not meets the PSTR requirements well. An important remark that allows us to confirm the above results is that the exposed threshold is close to 0.1 . The direct effect of financial development is positive and statistically significant at the $1 \%$ level on non-resource tax revenue. Indeed, the analysis shows that one-point rise in financial development index is accompanied by 7.98 percentage revenue-based tax enhancement point. Offer economic explanation for this impact, the study merges this quote with the standard error of the financial development measure, which is 7.9325. Thus, increase in financial development index of predictable error is coupled with increase in non-resource tax income $63.33(=7.9835 * 7.9325)$ percentage points. Direct effect of financial markets is positive but insignificant on non-resource tax revenues. Interaction between the institutional quality index, financial development, institutional quality and financial markets is statistically and robustly negative at the $1 \%$ level in both regressions, suggesting that a minimum of institutional quality is required to promote the enhanced effects of financial development and financial markets on tax revenues. Indeed, a one standard deviation increase in the interaction between these variables is correlated with a decrease in non-resource tax income of $-2.13(=-9.2331 * 0.2302)$ and $-0.72(=-4.3387 * 0.1666)$ percentage points for financial development model and stock markets model, respectively. Thus, we can say that better institutional quality is associated with a positive connection financial development and financial markets tax revenues that do not come from resources from the lower to the higher regime. As institutional quality improves, the greater the positive financial development and financial markets on non-resource tax revenues. These results are consistent with the rationale that improving institutional quality is critical to ensuring the effectiveness of financial development and financial markets in mobilizing non-resource tax revenues. They corroborate studies in literature among them Nnyanzi et al (2018).
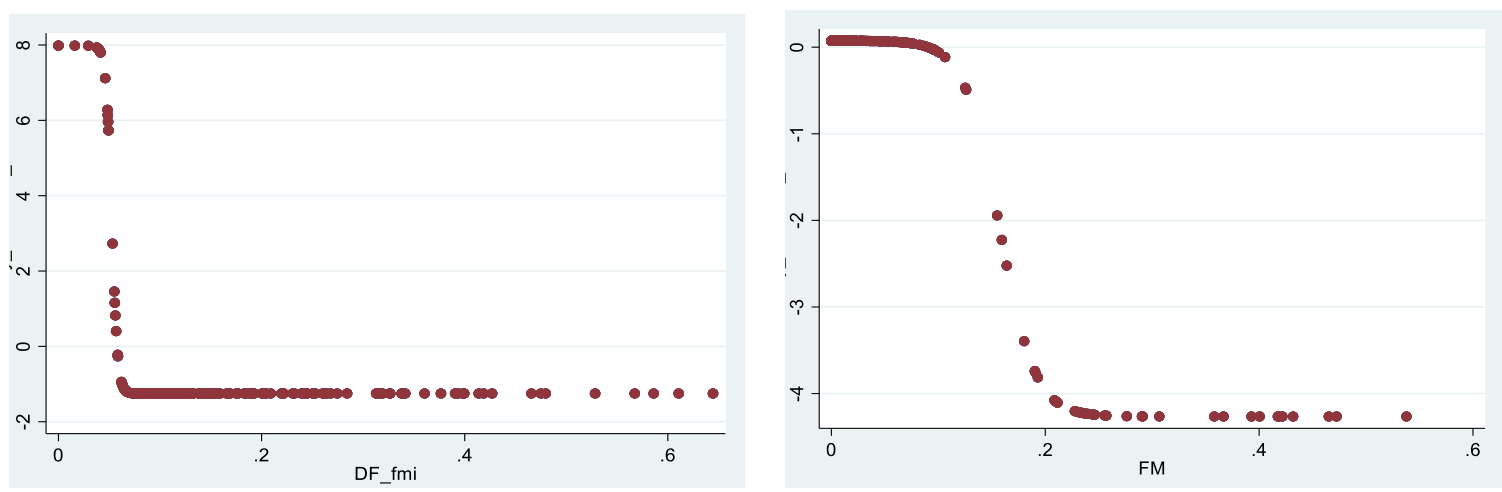

Figure 1. Tax revenue / Financial development elasticity and financial markets elasticity conditional on corruption control index, PSTR

Source: Authors estimates

Table 3. PSTR results of estimation 


\begin{tabular}{|c|c|c|c|c|}
\hline Dependent variable & \multicolumn{4}{|c|}{ Non-resource tax revenues } \\
\hline \multirow[t]{2}{*}{ Threshold variable } & \multicolumn{2}{|c|}{ Financial Development } & \multicolumn{2}{|c|}{ Financial Markets } \\
\hline & Coef & T-Student & Coef & udent \\
\hline$\alpha_{0}$ Financial development & $7.9835 * * *$ & $(2.2955)$ & & \\
\hline$\alpha_{1}$ Financial development $\times f$ & $-9.2331 * * *$ & $(-2.6527)$ & & \\
\hline$\alpha_{0}$ Financial markets & & & 0.0743 & $(0.1734)$ \\
\hline$\alpha_{1}$ Financial markets $\times f$ & & & $-4.3387 * * *$ & $(-2.6373)$ \\
\hline Loc parameter & & & & \\
\hline Slope parameter & & & & \\
\hline \multicolumn{5}{|l|}{ Control variables } \\
\hline GDP per capita growth & -0.5868 & $(-0.7662)$ & 0.1079 & $(1.0461)$ \\
\hline Agriculture value & $-0.3500 * * *$ & $(-3.0772)$ & $-0.1277 * * *$ & $(-2.9787)$ \\
\hline Manufacturing value & $-1.9471 * * *$ & $(-3.2853)$ & $-0.1987 * * *$ & $(-3.6555)$ \\
\hline Inflation & -0.0007 & $(-0.0254)$ & -0.0057 & $(-0.9240)$ \\
\hline Trade Openness & $-0.3611 * * *$ & $(-8.8316)$ & $0.0939 * * *$ & $(4.3852)$ \\
\hline Population growth & $32.2839 * * *$ & $(13.5860)$ & $-0.1035 * * *$ & $(-0.4117)$ \\
\hline RSS & \multicolumn{2}{|c|}{1112.775} & \multicolumn{2}{|c|}{1385.447} \\
\hline Number of observations & \multicolumn{2}{|c|}{270} & \multicolumn{2}{|r|}{270} \\
\hline
\end{tabular}

Source: Authors estimations. $* * *$ and $* * *$ show meaning at the 10,5 , and 1 percent level, accordingly.

For control variables, signs and meanings in PSTR are very similar to those in the simple panel regressions. However, the PSTR estimates most often have higher estimates than the first regressions. Growth rate of real per capita income has a negative but insignificant effect on non-resource tax income in the model with financial development and a positive but also insignificant effect in the model with financial markets. This implies that sub-Saharan African countries tend to have high non-resource tax revenues. This may suggest that these countries are making efforts to levy the tax revenues (terms of percentage of GDP), but much remains to be done, particularly in terms of the quality of institutions, to ensure that these efforts have an effect non-resources -related tax revenues. Indeed, insignificance of growth rate of real per capita income could be explained by the fact that the reforms undertaken to improve revenue mobilization have not yet led to their full potential for economic growth in order to significantly enhance well-being, and thus help to ensure good quality service degrees leading to higher tax revenues.

An increase in the share of value added in the agricultural sector has a negative and significant effect at the $1 \%$ level on non-resource tax revenues in both models, which is consistent with our predictions. Thus, a one standard deviation increase in value added in the agricultural sector is associated with a drop in non-resource tax revenues of -4.95 (= $-0.3500 * 14.1287)$ and $-1.80(=-0.1277 * 14.1287)$ percentage points for the model with financial development and the model with financial markets, respectively. This could be due to the difficulties of taxing income in this sector, which accounts for a large share of employment in these countries. Contrary to our predictions, the share of value added in the manufacturing sector exerts a negative and statistically significant effect at the $1 \%$ level on non-resource tax revenues in both models. An increase in the share of value added in the manufacturing sector by one standard deviation leads to a decrease of $-9.33(=-1.9471 * 4.7908)$ and $-0.95(=-0.1987 * 4.7908)$ for the model with financial development and the one with financial markets respectively. The concentration of the corporate tax on a small number of firms could be an explanation for this fact on value created in the manufacturing industry. The inflation rate is negatively but insignificantly associated with non-resource tax revenues in both models.

Trade openness negatively and significantly affects tax revenues or resources at $1 \%$ threshold in model with financial development, which is contrary to our expectations. When countries become more open to the world by one standard deviation, non-resource tax revenues in the model with financial development fall by $-9.66(=-0.3611 * 26.7476)$. But trade openness has a positive and significant effect at the $1 \%$ level on non-resource tax revenues in the model with financial markets. average standard error rise of one in trade openness results in an improvement of the in non-resource tax revenues of $-2.51(=0.0939 * 26.7476)$.

An increase in the population growth rate is positively and significantly associated at the $1 \%$ level with non-resource tax revenues in the model with financial performance. Thus, the increase in population per unit deviation is related to an improvement in tax revenue that is not associated with state resources $30.64(=32.2839 * 0.9490)$. However, its effect on non-resource-based tax revenues is negative and meaningful in the model with financial markets at the $1 \%$ level. When the population growth rate improves by one standard deviation, non-resource tax revenues fall by $0.1(-0.1035 * 0.9490)$. 


\section{Conclusion}

This paper analyzes the influence of financial development on fiscal revenues conditioned by level institutional quality for a panel of developing countries over the period 1990-2019. A number of papers have shown that institutional quality can hamper governments' efforts to raise tax revenues. Analysis is based on tax revenue that does not depend on resources as a variable of tax revenue, while for financial development it uses index of financial development and the financial market index developed by Svirydzenka (2016). Using a threshold approach, the results highlight that the influence of financial development and financial markets on non-income tax revenues is non-linear and depends on the quality of institutions. Financial development and financial markets increase tax revenue when institutional quality is improved. They also suggest that disparities across countries and time matter.

Policy implications of its results argue for tax reforms aimed at expanding the tax space and boosting a country's tax revenue mobilization. They suggest that the quality of institutions and improving tax reforms quality are critical sustaining effective tax revenue mobilization. The fact that some countries show a downward trend despite commitments to improve the quality of tax reforms and institutions suggests that more effective efforts are still needed. Therefore, countries and their partners must intensify their joint efforts to strengthen actions, reforms, and the institutional framework. However, our results suggest that tailored policies will ensure effective results depending on the level of the institutional environment in each country. Reform priorities may vary across countries and over time.

\section{References}

Agbeyegbe, T. D., Stotsky, J., \& WoldeMariam, A. (2006). Trade liberalization, exchange rate changes, and tax revenue in Sub-Saharan Africa. Journal of Asian Economics, 17(2), 261-284. https://doi.org/10.1016/j.asieco.2005.09.003

Ahamed, M. M. (2016). Does inclusive financial development matter for firms' tax evasion? Evidence from developing countries. Economics Letters, 149, 15-19. https://doi.org/10.1016/j.econlet.2016.10.003

Aizenman, J., Jinjarak, Y., Nguyen, H. T. K., \& Park, D. (2019). Fiscal space and government-spending and tax-rate cyclicality patterns: A cross-country comparison, 1960-2016. Journal of Macroeconomics, 60, 229-252. https://doi.org/10.1016/j.jmacro.2019.02.006

Akçay, S., Sağbaş, İ., \& Demirtaş, G. (2016). Financial Development and Tax Revenue Nexus in Turkey, Journal of Economics and Development Studies, 4(1), 103-108. https://doi.org/10.15640/jeds.v4n1a10

Akram, N. (2016). Do Financial Sector Activities Affect Tax Revenue in Pakistan?, The Lahore Journal of Economics, 21(2), 153-169. https://doi.org/10.35536/lje.2016.v21.i2.a6

Alesina A., \& Perotti R. (1996). Income Distribution, Political Instability, and Investment, European Economic Review, 40, 1203-28. https://doi.org/10.1016/0014-2921(95)00030-5

Alesina A., Özler S., Roubini N., \& Swagel P. (1996). Political Instability and Economic Growth. Journal of Economic Growth, 1, 189-211. https://doi.org/10.1007/BF00138862

Bassey, O. E. (2018). Financial sector development and tax revenue in Nigeria, International Journal of Economics, Commerce and Management, VI(6). Retrieved from http://ijecm.co.uk/

Benedek D., Crivelli E., Gupta S., \& Muthoora P. S. (2012). Foreign Aid and Revenue: Still a Crowding Out Effect?, IMF Working Papers, WP/12/186. https://doi.org/10.5089/9781475505344.001

Béreau, S., Villavicencio, A. L., \& Mignon, V. (2012). Currency Misalignments and Growth: A New Look Using Nonlinear Panel Data Methods. Applied Economics, 44, 3503-11. https://doi.org/10.1080/00036846.2011.577022

Bird, R. M., Martinez-Vazquez, J., \& Torgler, B. (2008). Tax Effort in Developing Countries and High-Income Countries: The Impact of Corruption, Voice and Accountability, Economic Analysis and Policy, 38(1), 55-71. https://doi.org/10.1016/S0313-5926(08)50006-3

Bittencourt, M., Gupta, R., \& Stander, L. (2014). Tax evasion, financial development and inflation: Theory and empirical evidence. Journal of Banking \& Finance, 41, 194-208. https://doi.org/10.1016/j.jbankfin.2014.01.009

Brun, J. F., Chambas, G., \& Mansour, M. (2015). Tax Effort of Developing Countries: An Alternative Measure, Chapter 11. In Financing Sustainable Development - Addressing Vulnerabilities, Boussichas, M., Guillaumont, P. (eds.), Ferdi, Economica, Paris, 467, 205-216.

Capasso, S., \& Jappelli, T. (2013). Financial development and the underground economy. Journal of Development Economics, 101, 167-178. https://doi.org/10.1016/j.jdeveco.2012.10.005

Carmignani, F. (2003). Political Instability, Uncertainty and Economics, Journal of Economic Surveys, 17, 1-54. https://doi.org/10.1111/1467-6419.00187

Clist, P., \& Morrissey, O. (2011). Aid and Tax Revenue: Signs of a Positive Effect since the 1980s. Journal of 
International Development, 23, 165-80. https://doi.org/10.1002/jid.1656

Colletaz G., \& Hurlin C. (2006). Threshold Effects of the Public Capital Productivity: An International Panel Smooth Transition Approach. Document de Recherche du Laboratoire d'Economie d'Orléans, 2006-1.

Dabla-Norris, E., \& Koeda, J. (2008). Informality and Bank Credit: Evidence from Firm-Level Data.IMF Working Paper, WP/08/94. https://doi.org/10.5089/9781451869552.001

Fok, D., Van Dijk, D., \& Franses, P. H. (2005). A Multi-level Panel STAR Model for US Manufacturing Sectors. Journal of Applied Econometrics, 20, 811-27. https://doi.org/10.1002/jae.822

Fouquau J., Hurlin C., \& Rabaud I. (2008). The Feldstein - Horioka Puzzle: A Panel Smooth Transition Regression Approach. Economic Modelling, 25, 287-99. https://doi.org/10.1016/j.econmod.2007.06.008

Fox, W. F., \& Gurley, T. (2005). An Exploration of Tax Patterns Around the World. Tax Notes International, 28,793-805.

Gnangnon, S. K. (2019). Tax Reform and Trade Openness in Developing Countries. Journal of Economic Integration, 34(3), 498-519. https://doi.org/10.11130/jei.2019.34.3.498

Gnangnon, S. K., \& Brun, J. F. (2017). Impact of export upgrading on tax revenue in developing and high-income countries. Oxford Development Studies, 45(4), 542-561. https://doi.org/10.1080/13600818.2017.1313398

Gnangnon, S. K., \& Brun, J. F. (2018). Impact of bridging the Internet gap on public revenue mobilization. Information Economics and Policy, 43, 23-33. https://doi.org/10.1016/j.infoecopol.2018.04.001

González A., Teräsvirta T., \& van Dijk, D. (2005). Panel Smooth Transition Regression Models, SSE/ EFI Working Paper Series in Economics and Finance, 604. Retrieved from http://hdl.handle.net/10419/56363

Granger, C. W., \& Teräsvirta, T. (1993). Modelling Non-Linear Economic Relationships. Oxford: Oxford University Press. Retrieved from http://ukcatalogue.o ... uct/9780198773207.do

Greenwood, J., \& Smith, B. D. (1997). Financial markets in development, and the development of financial markets. Journal of Economic Dynamics and Control, 21(1), 145-181. https://doi.org/10.1016/0165-1889(95)00928-0

Guo, J. T., \& Fu-Sheng, H. (2020). Tax Evasion and Financial Development under Asymmetric Information in Credit Markets. Journal of Development Economics, 145(June), 102463. https://doi.org/10.1016/j.jdeveco.2020.102463

Gupta, A. S. (2007). Determinants of Tax Revenue Efforts in Developing Countries. IMF Working Paper, WP/07/184, Washington: International Monetary Fund. https://doi.org/10.5089/9781451867480.001

Hansen B. E. (1999). Threshold Effects in Non-dynamic Panels: Estimation, Testing, and Inference. Journal of Econometrics, 93, 345-68. https://doi.org/10.1111/1467-6419.00187

Ilievski, B. (2012). Tax Revenue and financial development: Theory and Evidence. PhD Dissertation, Southern Illinois University Carbondale, USA.

Ilievski, B. (2015). Stock markets and tax revenue. Journal of Applied Finance \& Banking, 5(3), 1-16.

Islam, M. A., Liu, H., Khan, M. A., Reza, S. M., Yahia, Y. E., \& Nasrin, L. (2018). Causal Relationship between Economic Growth, Financial Deepening, Foreign Direct Investment and Innovation: Evidence from China. Asian Econ. Financ. Rev., 8, 1086-1101. https://doi.org/10.18488/journal.aefr.2018.88.1086.1101

Jude, C., \& Levieuge, G. (2013). Growth Effect of FDI in Developing Economies: The Role of Institutional Quality, Document de Recherche du Laboratoire d'Economie d'Orléans, 2013-11. https://doi.org/10.2139/ssrn.2409656

Kaufmann, D., Kraay, A., \& Mastruzzi, M. (2008). Governance Matters VIII: Aggregate and Individual Governance Indicators for 1996-2008. World Bank Policy Research Working Paper No. 4978. Washington, D.C. https://doi.org/10.1596/1813-9450-4978

Khan, M. A., Abdulahi, M. E., Liaqat, I., \& Shah, S. S. H. (2019). Institutional quality and financial development: The United States perspective. J. Multinatl. Financ. Manag, 49, 67-80.

https://doi.org/10.1016/j.mulfin.2019.01.001

Lompo, A. A. B. (2021). How Financial Sector Development Improve Tax Revenue Mobilization for Developing Countries? Études et Documents $n^{\circ} 24$, CERDI. Retrieved from https://hal.uca.fr/hal-03328502

Mahdavi, S. (2008). The Level and Composition of Tax Revenue in Developing Countries; Evidence from Unbalanced paneldata. International Reviewof Economics and Finance, 17(2008), 607-617.

https://doi.org/10.1016/j.iref.2008.01.001

McNabb, K. (2017). Toward Closer Cohesion of International Tax Statistics. WIDER Working Paper 184/2017. 
https://doi.org/10.35188/UNU-WIDER/2017/410-0

Nnyanzi, J. B., Bbale, J. M., \& Sendi, R. (2018). Financial Development and Tax Revenue: How Catalytic Are Political Development and Corruption? International Journal of Economics and Finance; 10(8), 2018. https://doi.org/10.5539/ijef.v10n8p92

Petrescu, I. (2013). Financial Sector Quality and Tax Revenue: Panel Evidence. Mimeo, University of Maryland.

Prichard, W., Cobham, A., \& Goodall, A. (2014). The ICTD Government Revenue Dataset, ICTD Working Paper, 19. https://doi.org/10.2139/ssrn.2496442

Rodrik, D. (1998). Why do more open economies have bigger governments? Journal of Political Economy, 106, 997-1032. https://doi.org/10.1086/250038

Svirydzenka, K. (2016). Introducing a New Broad-based Index of Financial Development. IMF Working Paper, WP/16/5. https://doi.org/10.5089/9781513583709.001

Taha, R., Colombage, S. R. N., Maslyuk, S., \& Nanthakumar, L. (2013). Does financial system activity affect tax revenue in Malaysia? Bounds testing and causality approach. Journal of Asian Economics, 24, 147-157. https://doi.org/10.1016/j.asieco.2012.11.001

Tanzi, V. (1992). Fiscal policy and economic reconstruction in Latin America. World Development, 20(5), 641-657. https://doi.org/10.1016/0305-750X(92)90143-J

Tanzi, V., \& Davoodi, H. (2000). Corruption, Public Invesment, and Growth. IMF Working Paper, WP/97/139. https://doi.org/10.5089/9781451929515.001

Tanzi, V., \& Zee, H. (2000). Tax policy for emerging markets: Developing Countries. National Tax Journal, 2000, 299-322. https://doi.org/10.17310/ntj.2000.2.07

Torgler, B. (2003a). Tax Morale and Institutions, CREMA Working Paper Series 2003-09, Center for Research in Economics, Management and the Arts (CREMA). https://doi.org/10.2139/ssrn.663686

Torgler, B. (2003b). Tax morale in transition countries, Post-Communist Economies, 15, 357-81. https://doi.org/10.1080/1463137032000139052

Torgler, B., Demir, I. C., Macintyre, A., \& Schaffner, M. (2008). Causes and consequences of tax morale: An empirical investigation. Economic Analysis and Policy, 38(2), 313-339. https://doi.org/10.1016/S0313-5926(08)50023-3

Yohou, H., Goujon, D., Michäl, M., \& Ouattara, W. (2016). Heterogeneous Aid Effects on Tax Revenues: Accounting for Government Stability in WAEMU Countries. Journal of African Economies, 1-31. https://doi.org/10.1093/jae/ejw003

Yu, P. (2013). Inconsistency of 2SLS Estimators in Threshold Regression with Endogeneity, Economics Letters, 120, 532-536. https://doi.org/10.1016/j.econlet.2013.06.023

Yu, P., \& Phillips, P. C. B. (2014). Threshold Regression with Endogeneity, SSRN, Cowles Foundation Discussion Paper. https://doi.org/10.2139/ssrn.2533013 


\section{Appendices}

Appendix 1: Definition and Source of variables

\begin{tabular}{|c|c|}
\hline Variables & Definition \\
\hline Tax & $\begin{array}{l}\text { It is the proportion of a country's total non-resource tax revenue as a } \\
\text { percentage of GDP, which is the difference between total tax } \\
\text { revenue excluding grants and social transfers (as a percentage of } \\
\text { GDP) and resource tax revenue (as a percentage of GDP), the last of } \\
\text { which is the tax revenue received from natural resources. }\end{array}$ \\
\hline $\begin{array}{l}\text { Financial } \\
\text { development }\end{array}$ & $\begin{array}{l}\text { Financial development is defined as a combination of depth (size } \\
\text { and liquidity of markets), access (ability of individuals and } \\
\text { companies to access financial services), and efficiency (ability of } \\
\text { institutions to provide financial services at low cost and with } \\
\text { sustainable revenues, and the level of activity of capital markets). }\end{array}$ \\
\hline Financial Markets & $\begin{array}{l}\text { Measuring the degree of overall growth of the financial markets. } \\
\text { It is a hybrid index of six governance indices, namely control of } \\
\text { corruption, government effectiveness, political stability and absence } \\
\text { of violence/terrorism, regulatory quality, rule of law, and voice and } \\
\text { accountability. This indicator has been computed by relying on the }\end{array}$ \\
\hline $\begin{array}{l}\text { Institutional } \\
\text { quality }\end{array}$ & $\begin{array}{l}\text { factor analysis approach, including the Principal Component } \\
\text { Analysis that allows to extract a common factor from the } \\
\text { above-mentioned six indicators of governance. Higher values of } \\
\text { "institutional quality" reflect higher quality of governence, and } \\
\text { lower values indicate lower level of institutional quality. }\end{array}$ \\
\hline
\end{tabular}

Sources

ICTD Public Revenue Dataset. See online:

https://www.wider.unu.edu/project/g overnment-revenue-dataset

Svirydzenka (2016)

Svirydzenka (2016)

Annual percentage growth rate of GDP per capita based on constant local currency. GDP per capita is gross domestic product divided by GDP per capita midyear population. GDP at purchaser's prices is the sum of gross growth value added by all resident producers in the economy plus any product taxes and minus any subsidies not included in the value of the products.

Agriculture share Agriculture in poorer countries is generally a subsistence activity, so in GDP countries dominated by this sector may be expected to raise less revenue

The manufacturing sector tends to be more formal than the

Manufacturing agricultural sector in developing countries. So, it becomes easier to

share in GDP collect taxes from the former. Countries dominated by this sector are likely to raise more revenue.

Inflation is a proxy for the effect of macroeconomic policies. The

Inflation worse the macroeconomic situation, the lower the revenues from different taxes.

with a large international trade sector tends to be one that is well

Openness organized and monetized, so the costs of tax administration is likely to be lower.

Annual population growth rate. Population is based on the de facto

Population growth definition of population, which counts all residents regardless of legal status or citizenship.

WID

WID

WDI

Weo

WDI

WDI

WIG 
Appendix 3: List of countries of the full sample

\begin{tabular}{llll}
\hline Angola & Chad & Guinea & Nigeria \\
Benin & Congo, Democratic Republic & Guinea-Bissau & Rwanda \\
Botswana & Congo, Republic & Kenya & Sierra Leone \\
Burkina Faso & Côte d'Ivoire & Malawi & South Africa \\
Burundi & Gabon & Mauritius & Togo \\
Cabo Verde & Gambia, & Mozambique & Uganda \\
Cameroon & Ghana & Namibia & Zambia \\
& & Niger & \\
\hline
\end{tabular}

\section{Copyrights}

Copyright for this article is retained by the author(s), with first publication rights granted to the journal.

This is an open-access article distributed under the terms and conditions of the Creative Commons Attribution license which permits unrestricted use, distribution, and reproduction in any medium, provided the original work is properly cited. 